\title{
Health Benefits of Pea Protein Isolate: A
} Comparative Review

\section{Kaden Stilling}

Department of Human Health and Nutrition, College of Biological Sciences, University of Guelph, Guelph, ON Canada. Faculty supervisor: Dr. Monk For correspondence, please email: kadenstilling@gmail.com

\section{Abstract}

Pea protein isolate, derived from yellow split peas, is an increasingly prevalent additive and supplement in the food and beverage market, commonly found in alternative meats, meal replacements, cereal bars, alternative milks and additional food products. With pea protein isolate being relatively new to the market, there is not extensive research on its health benefits to coincide with its rising popularity. This review aims to cover the existing body of evidence to connect the known potential health benefits of pea protein isolate, as well as compare these health benefits to other protein alternatives that have been comprehensively researched such as soy and whey protein. The health benefits identified include its anabolic properties, high satiety effect, glycaemic-lowering effect, hypolipidemic effect and blood pressure lowering effect involving the renin-angiotensin-aldosterone system.

Keywords: pea protein, cardiovascular, satiety, soy, whey, anabolic

\section{Introduction}

The objective of this review is to evaluate the existing literature on pea protein isolate and its health effects on the human body. It will also compare it to that of other protein alternatives such as soy and whey protein. Pea protein isolate is derived from yellow split peas, in a manufacturing process that dries the peas out and is isolated into a proteinrich powder that can used as an additive to a diverse group food and beverages [1]. It is important to note that in isolating the protein from the yellow split pea, it is unknown which physiological properties will remain in the substance.

The extraction process of protein from the yellow pea varies from company to company, using various techniques such as alkaline extraction, isoelectric precipitation or salt extraction and micellization [2]. This will create a variety of different compositions of the pea protein isolates on the market, with some containing higher contents of other nutrients aside from protein such as fibre, starch, iron, sodium and fat. These varying nutrient levels can be seen from product to product on nutrition levels, however, some phytochemical and phytate levels are relatively unknown in the protein isolates. For example, whole yellow peas have been known to contain alkaloids, flavonoids, isoflavones, saponins, tannins, quercetin and other phytochemicals [3]. Physiological properties from these bioactives from the whole food include antibacterial, antifungal, anticancerous and anti-inflammatory effects [3]. Some phytochemicals have been documented to change in levels such as polyphenols - which are known to have antioxidant activity in yellow peas - depending on the extraction process [2]. Companies producing PPI could choose to reduce polyphenol levels due to its ability to decrease protein digestibility [2]. Whether or not other bioactives remain in the isolate is unknown, and the effects have yet to be evaluated.

From 2011 to 2015,170 products containing pea protein isolate entered the market worldwide [4]. From just January to March of 2016, when the Canadian Analysis Report of pea protein isolate came out, another 47 of these products launched, showing the large surge that the market is seeing in pea protein isolate products [4]. The two most predominant countries that these products are launching in are Canada and the United States, with some of the notable companies carrying the products being Beyond Meat, Daiya Foods, Loblaws and more. The products are often found in cereal bars, milk alternatives, meat alternatives and meal replacements [4].

A potential reason for the initial attraction of consumers to these products could be attributed to the vast inclusiveness in diets. The majority of the claims made by the product manufacturers include: no/low/reduced allergens, gluten-free, lactose-free, vegan and genetically modified organism (GMO) free [4]. The rising prevalence of pea protein isolate is very evident in the North American markets, however, few studies have been conducted in contrast to its thoroughly researched protein alternatives and the health effects they have on the human body.

\section{Methods}

The search terms "pea protein" and "pea protein isolate" were used on the databases National Center for Biotechnology 
Information (NCBI) and Primo. The time of the search was from September 2019 to November 2019. All 11 research articles identified as pertaining to the health effects of pea protein or pea protein isolate were included due to the low amount of research available. Protein and amino acid composition is not included in this list, as the articles did not apply the results to their potential health benefits.

\section{Results}

\section{Protein and Amino Acid Composition}

The protein and amino acid composition is important to determine in order to evaluate the quality of the protein based off the demands of the body. Gorissen et al. compared the protein content and amino acid composition of a wide variety of plant-based protein isolates and animal-based protein isolates against each other [5]. Pea protein isolate (PPI) contained the third highest protein content percentage (81\%) of the fifteen isolates tested, only lower than wheat protein and caseinate protein [5]. This includes being higher in protein content than popularly supplemented hemp and soy protein [5].

Essential amino acids (EAA) are a class of amino acids that cannot be synthesized by the human body, thus must be consumed through one's diet [6]. The World Health Organization (WHO) and Food and Agriculture Organization (FAO) have been collaborating since 1949 in the aims of quantifying energy and nutrient requirements in populations [6]. Since then, they have been updating their information for increased accuracy. With the joint effort of the United Nations University, their 2007 study updated the EAA requirements using stable isotope studies instead of nitrogen balances to establish updated adequate intakes [6]. Using these values, Gorissen et al. determined the percentage of EAA per the total protein consumed [5]. This tended to be higher in the animalbased protein, although pea protein still met the WHO/FAO/UNU requirements in adults, with only potato protein containing more EAA for plant-based proteins [5]. Pea protein was higher than hemp and soy in EAA percentage but fell below whey protein [5].

Although pea protein met the EAA dose requirements of the $\mathrm{WHO}$, methionine content was well below the recommendation [5]. Relying on pea protein as a primary protein source could therefore result in a methionine deficiency, which could pose health threats such as oxidative stress, particularly in the liver [7]. Specifically looking at branched-chain amino acids, which have been demonstrated to play a large role in muscle anabolism, pea protein contained high amounts of leucine, and valine and isoleucine were higher than most plant-based proteins, however still lower than the animal-based proteins $[5,8]$. The protein digestibility corrected amino acid score (PDCAAS) of PPI is 93\%, which is much higher than most plant-based proteins, and is comparable to that of egg whites, casein, and soy protein [9]. The high EAA, low methionine and high BCAA — particularly leucine-properties are shown throughout various studies discussed in this review which support the findings from Gorissen et al. Combining this with pea protein's high emulsifying properties and low impact on product texture, pea protein can be used as an effective supplement or additive in food and beverages [10].

\section{Genotoxicity}

Genotoxicity is the process that causes damage to genetic material, which is why its regulation is crucial for new products entering the food market for direct human consumption [11]. Aouatif et al. evaluated the safety of the pea protein isolates, specifically from NUTRALYS and its genotoxic potential [12]. In this study, three first barrier trials were used. Firstly, the PPI did not show a positive result of identifying point and frameshift mutations in the Ames bacterial reverse mutation test [12]. The second test was an in vitro chromosomal aberration test and the PPI again did not induce chromosomal aberrations in the presence or absence of metabolic activation in human lymphocytes [12]. Lastly, an in vivo mice bone marrow micronucleus assay was used and once again the PPI did not induce significant increases of micronucleated immature erythrocytes in the bone marrow [12]. Thus, it was concluded that NUTRALYS PPI is nonmutagenic and nongenotoxic from the 3 first line tests used [12]. Further research could be conducted based off of Auoatif et al.'s study; however, current research efforts are seemingly aimed at other properties of PPI.

\section{Fortification Properties}

This review does not go into depth about pea protein's functional emulsion properties, however, a 2019 study by Almajwal et al. evaluated the stability of vitamin D in PPI nanoemulsions [13]. Due to the pulse's high ability to absorb oil-water interfaces and form films, a potential new application may have been discovered for PPI aside from a food additive or supplement for protein [13]. 35 vitamin D deficient rats were used, divided into four groups: PPI nanoemulsion, with and without vitamin $\mathrm{D}$ and canola oilbased control, and with and without vitamin D [13]. After one week, rats receiving PPI nanoemulsions with vitamin D had significantly higher circulating $25(\mathrm{OH})$ Vitamin D than before treatment and the controls. Vitamin D deficient biomarkers including parathyroid hormone (PTH), calcium, phosphorus and alkaline phosphatase (ALP) were significantly lower, aiding in the restoration from deficiency [13]. Histological evaluations showed significant improvements in the osteoid area rather than the trabecular separations. Although this study does not evaluate any mechanisms or explore bioavailability and pharmacokinetics of vitamin $\mathrm{D}$, it opened a basis for a multitude of future research that can stem from this. For example, whether other fat-soluble vitamins can be supplemented with PPI nanoemulsions or perhaps if PPI increases fat-soluble vitamins when added as a protein source itself. 


\section{Anabolic Property}

Athletes on a plant-based diet, or with dietary restrictions like dairy-free, low allergens, vegan, or glutenfree, may seek plant-based protein supplementation and the common sources are soy and pea protein [14]. More studies have evaluated soy protein in comparison to whey, showing equal anabolic effects in resistance training in four studies, however, a more recent study in 2013 showed whey protein eliciting greater anabolic effects [15-19]. A potential drawback from soy protein supplementation being a plantbased alternative to whey is that the inconclusive literature has shown soy protein to contain phytoestrogens that could negatively affect endogenous sex hormone levels that can cause multiple physiological problems [20-22]. Avoiding the potential harmful phytoestrogens in soy could be another reason to choose pea protein over soy protein. The pea family Pisum sativum has also been known to have a favourable phytochemical profile [23]

NUTRALYS pea protein isolate was used in a study that compared pea protein supplementation, whey protein supplementation and placebo in a double-blind randomized clinical trial on muscle thickness gains using ultrasonography during resistance training [24]. 161 males, aged 18-35 years, were placed into the 3 groups, taking $25 \mathrm{~g}$ of protein or placebo twice a day for 12 weeks in a training program that occurred 3 times a week [24]. Measurements of muscle mass, strength and tolerance - the quantification of adverse effects when factoring in experimental compliance-were made initially at day 0 , at halfway at day 42 and the final measurements at day 84 [24]. Strength, based off 1-rep maximums, did not significantly differ between any of the control groups compared to the placebo [24]. This study did effectively show that pea protein supplement significantly promoted increased biceps brachii thickness during this set workout trial compared to the control $\mathrm{p}=0.0001$, and while the pea protein group thickness was higher than the whey, it did not prove to be significant $(\mathrm{p}=0.09)$ [24]. These effects were greater in individuals who had never engaged in, or were just returning to, resistance training [24]. This supports the idea that pea protein can be used as an effective whey alternative for protein supplementation without sacrificing any anabolic properties. It is also important to note that biceps brachii is an isolated measurement compared to whole body measurements, which is addressed in the next study discussed.

An additional study that was published four years later also evaluated pea protein's anabolic properties compared to whey protein [25]. However, this study used significantly fewer participants, using only 8 males and 7 females, with both sexes participating in each control group [25]. This study did control for previous training experience, only including trained individuals [25]. Banaszek et al. used an 8-week highintensity functional training (HIFT) of 4 times a week, both sexes taking $24 \mathrm{~g}$ of protein twice a day [25]. This study provided thorough forms of calculating the physiological adaptations, including: rectus femoris and vastus lateralis thickness, body fat percentage based off of bioelectrical impedance analysis, 1 repetition maximum (1RM) of squat and deadlift and isometric mid-thigh pull (IMTP) performance for force development and peak force [25]. Both the whey protein and pea protein groups showed increased strength of 1RM squat and deadlift, however no other significant measures of physiological adaptations [25]. Alongside this, there were no differences between whey and pea protein in these measurements, again supporting that pea protein can be used as an effective alternative for whey protein [25].

Since only one study each for resistance training and high intensity exercise training is a very limited amount, more studies evaluating similar athletic programs for muscle building are needed to reliably prove pea protein as a viable whey protein equivalent. A study targeting the elderly to show pea protein's ability to prevent muscle wasting has not been done and would be beneficial for a wider demographic.

\section{Satiety and Blood Glucose}

Satiety, the feeling of fullness, has immense implications on weight management due to its ability to influence the body's caloric intake [26]. Smith et al.'s study in 2015 aimed to isolate which component of the yellow split pea is responsible for the known property of the pulse's ability to lower blood glucose and raise satiety. To explore this, 19 healthy male participants aged 20-30 years old were recruited from the University of Toronto [27]. Exclusion principles included females, BMI outside of the range of 20.0-24.9 $\mathrm{kg} / \mathrm{m}^{2}$, smokers, breakfast skippers and those on medication, with metabolic disorders or scoring greater than or equal to 11 on an Eating Habits Questionnaire [27]. Participants were given five treatments of tomato soup (control) with either $10 \mathrm{~g}$ (F10) or $20 \mathrm{~g}$ (F20) of yellow pea fibre, or $10 \mathrm{~g}$ (P10) or $20 \mathrm{~g}$ (P20) of Propulse PPI added [27]. The meals were isovolumetric and salt was added appropriately to ensure equal sodium values due to its satiety and glycaemia properties [27]. Timing of intake, sleep, body mass index, exercise, breakfast, overnight fasting, fatigue, thirst, palatability and alcohol intake were all additional controls, providing strength to this study [27]. Blood glucose, subjective appetite, physical comfort and energy fatigue were measured pre-meal and postmeal [27]. In the first experiment, pizza was fed ad libitum at 30 minutes post-tomato soup, and in the second experiment, pizza was fed ad libitum at 120 minutes post-tomato soup [27].

In the first experiment both P10 and P20 suppressed blood glucose pre-ad libitum meal significantly more than the control, however only P20 elicited this effect post-meal [27]. Due to this effect only occurring in the first experiment, this shows that pea protein has glycaemic-lowering properties short-term in this experiment. While using a single-blinded subjective measurement method to obtain appetite values, results showed decreased food intake in the first experiment only in the P20 group [27]. This supports the idea that pea protein is the source of the pulses' satiety, although also occurring in short term. The subjective portion of satiety measurements can be greatly improved, using anorexigenic hormone concentrations from blood samples instead. While 
much more invasive, the accuracy is crucial. Fibre was concluded to not be responsible for yellow split peas properties discussed, instead the protein component.

Overduin et al. explored PPI's satiety property by first evaluating in vitro gastric conditions for digestion of pea, whey and casein protein [28]. Pea protein temporarily aggregated during stomach digestion, unlike whey, although it had much smaller precipitates than casein, allowing for intermediate gastric retention, which contributes to the satietyinducing effect shown [28].

In the in vivo portion of this experiment, 12 male rats received 3 test foods with equal energy densities, and pea and whey protein content of $35 \%$, as well as a control with no protein. $10 \mathrm{~g}$ of test foods were consumed between 8-15 minutes after presentation [28]. Pea protein and whey protein elicited similar effects of significantly decreasing blood glucose at 40-60 minutes after the meal and significant cholecystokinin (CCK) (one of the three anorexigenic hormones measured) stimulation over the control [28]. Whey protein produced a significant effect in decreased ghrelin production and higher levels of plasma insulin at 40 minutes after the meal, although leveled out to match pea protein and the control with time [28]. This could be attributed to the slower bioavailability found in the in vitro study portion [28]. Pea, whey and the control elicited similar response curves of anorexigenic hormones peptide tyrosine tyrosine (PYY) and glucagon-like peptide (GLP-1) [28]. This study showed pea protein could effectively lower blood glucose and trigger gastrointestinal satiety signals, eliciting similar effects to that of whey protein [28]. While the methodology was extremely thorough to obtain accurate and detailed data, the sample sizes of the in vivo portion being $n=4$ is too small to be completely reliable. More studies upon which anorexigenic hormones PPI specifically induces will be beneficial, especially when exploring potential weight loss strategies.

\section{Lipid Metabolism}

The hypolipidemic effect of soy protein has been well documented, including an American Heart Association meta-analysis of 22 randomized controlled trials, which found an average of 3\% decrease in low density lipoprotein (LDL) cholesterol concentration with $50 \mathrm{~g}$ dosage of soy protein [29]. This is a relatively small decrease in contrast to the large average dose of $50 \mathrm{~g}$ soy protein [29]. No significant results were found on high density lipoprotein (HDL), triglyceride or lipoprotein concentrations [29]. In contrast to whey protein, another meta-analysis was conducted with 13 randomized controlled trials, only showing a significant decrease of triacylglycerol by $0.11 \mathrm{mmol} / \mathrm{L}$, although potentially disappearing in low body mass index individuals [30]. Since this study, pea protein prevalence has risen, and two studies were found exploring how pea protein affects lipid metabolism [31, 32].

Spielmann et al. used 24 Sprague-Dawley male rats divided into two groups, one being a casein fed control and the other PPI consuming for 16 days at $200 \mathrm{~g} / \mathrm{kg}$ dosage [31]. With the same food intake, pea protein fed rats had significantly lower body weight gain, absolute liver weight and liver weight per $100 \mathrm{~g}$ body weight than the casein control, hypothesized due to the limited tryptophan content in the pea protein [31]. Total cholesterol in the liver, plasma, very low density lipoprotein (VLDL), LDL and HDL and total triacylglycerol in the liver, plasma, VLDL, LDL, HDL, and fecal bile acids were all measured [31]. Of these, only liver cholesterol and VLDL levels were significantly decreased, and the bile acids in feces were increased over two-fold, both effects shown in the PPI group [31]. High VLDL levels are associated with the pathogenesis of atherosclerosis, thus, its excretion suggests a positive cardiovascular effect [33-36]. To evaluate potential mechanisms, relative mRNA expression was measured in sterol regulatory element-binding protein-1c (SREBP-1c), hydroxy-methyl-glutyral-CoA (HMG-CoA) reductase, cholesterol 7 $\alpha$-hydroxylase (CYP7A1) and LDL receptor levels, all of which were significantly elevated in the pea protein group versus casein control [31]. The mechanism behind the increased bile acid excretion could be attributed to the upregulated CYP7A1 concentrations [37]. The increased bile acid excretion would also explain the lower hepatic cholesterol concentrations observed, as demonstrated previously [38]. It was also hypothesized that the increased SREBP-2 and target genes of HMG-CoA reductase and LDL receptor in the hepatic tissue due to the increased bile acid synthesis. Grosskopf et al. found an association with the decreased bile acid secretion and an increased risk of coronary artery disease, thus, the increased bile acid synthesis seen in PPI should be expected to have a positive effect of cardiovascular health [39].

Rigamonti et al. also took 24 male rats, feeding them a hypercholesterolemic diet for one week. They then separated into two groups for 28 days with an ad libitum hypercholesterolemic diet, with one consuming a diet containing $20 \%$ of Pisane C9 PPI and the other $20 \%$ casein for the control diet [32]. Weight gain was not different between the two ad libitum groups [32]. Plasma total cholesterol, HDL cholesterol and triglyceride concentrations were all measured. Plasma total cholesterol and triglycerides levels in the pea protein group were both significantly lower than the casein control at both 14 and 28 days [32]. To explore potential mechanisms, Rigamonti et al. measured liver mRNA concentrations of various known genes that influence cholesterol synthesis, cholesterol uptake and bile acid synthesis [32]. The pea protein group has significantly higher mRNA levels of the low LDL receptor, the major regulator of circulating LDL cholesterol [32]. The SREBP-1c levels were not significantly lower, however, its target genes: fatty acid synthase, stearoyl-CoA desaturase-1 and stearoyl-CoA desaturase-2 were significantly lower [32]. These target genes play a role in hepatic cholesterol uptake and downregulating fatty acid synthesis genes [32]. Rigamonti et al. hypothesized it could be due to a reduced proteolytic activation of SREBP$1 \mathrm{c}$ thus reducing its activated transcription factor [32]. No other measured mRNA levels produced significantly different 
levels between pea protein and the control, including cholesterol $7 \alpha$-hydroxylase and HMG-CoA reductase [32].

These two studies produce similar results; the small differences can be attributed to completely different molecular pathways. More studies will need to be conducted to identify how pea protein elicits its hypolipidemic effects, as well as translating this to human trials to prove its relevance to human nutrition.

The hypolipidemic effects could translate into preventing cardiovascular disease, due to LDL, VLDL, and triglyceride all being commonly associated with atherosclerosis development [40]. Evaluating the relative risk of developing atherosclerosis itself, in either larger animal studies or human surveys would be beneficial to see if supplementation can be a preventative factor of the disease. Due to the long latency of the disease, and because of PPI being a relatively new product in the market, regular PPI intake will occur in low prevalence of the population, making it challenging for effective case-control studies. A longitudinal cohort study with regular PPI intake would be most effective and would test the potential preventative effects of the multiple cardiovascular diseases discussed, although would be difficult to conduct.

\section{Blood Pressure and Oxidative Stress}

The renin-angiotensin-aldosterone system (RAAS) plays a crucial role in regulating the blood pressure in the body [41]. The end product of this system, angiotensin II, will ultimately result in systemic vasoconstriction, increased water reabsorption and increased osmolarity of the blood, which leads to an integrated increase in blood pressure [41]. The enzymatic cascade that results in the activation of angiotensin II provides multiple sites of intervention to control blood pressure, for example the inhibition of angiotensin converting enzyme (ACE) which is responsible for the conversion of angiotensin I (inactive) to angiotensin II (active) [41]. Renin is another potential site of intervention, as renin serves as the precursor for angiotensin I formation [41].

Free radicals are believed to be involved in numerous cardiovascular diseases [42]. The oxidative stress from free radicals and reactive oxidative species is damaging to the vascular walls, promoting endothelial dysfunction and inducing an inflammatory response [42]. This chronic inflammation derived from free radicals is associated with cardiovascular diseases such as hypertension, atherosclerosis, congestive heart failure and myocardial infarctions [42].

Soy protein's effect on blood pressure has not been explored to the extent of its hypolipidemic effect, although a meta-analysis of postmenopausal women showed a 5.47 $\mathrm{mmHg}$ decreased in SBP with soy consumption [43]. Whey protein has shown blood pressure lowering effects in two recent randomized control trials as well as improved endothelial function, with the suggested mechanism being ACE inhibition [44, 45].

Humiski and Aluko's study from 2007 took commercial pea protein isolate from Nutri-Pea Limited called Propulse and tested multiple physiochemical properties with five separate proteases: alcalase, flavourzyme, papain, trypsin, and alphachymotrypsin, to create pea protein hydrolysates (PPH) [46]. All hydrolysates showed statistically significant inhibition of ACE, just surpassing 40\% inhibition, except for flavourzyme being just below, thus being the least effective protease [46]. Captopril ACE activity inhibition is $50 \%$ at just $2 \mathrm{ng} / \mathrm{mL}$ concentration for a comparative value [47].

This study also accounted for 1,1-diphenyl-2picrylhydrazyl (DPPH) scavenging ability of free radicals as well [46]. The scavenging activity ranged from 7-11\% DPPH scavenging effect [46]. Compared to other values of butylated hydroxytoluene $(85 \%)$ and wheat germ hydrosylate $(60 \%)$, the values of $\mathrm{PPH}$ were very low [48, 49]. Although it may produce a statistically significant number, the in vivo applications may be negligible.

Another study evaluated pea protein's in vitro effects. Barbana and Boye's study simulated gastrointestinal digestion, however, using chickpea and yellow pea concentrate, not isolates [50]. This study showed significant inhibition of ACE once again for the yellow pea, peaking over $70 \%$ inhibition at $0.7 \mathrm{mg} / \mathrm{mL}$ hydrolysate concentration, and also showing a dose-dependent relationship, using intervals of $0.1 \mathrm{mg} / \mathrm{mL}$ from 0 [50]. The inhibitory concentration that reduces enzymatic activity by $50 \%\left(\mathrm{IC}_{50}\right)$ value was $159 \pm 1$ for yellow pea proteins [50]. These values were very similar to the values of the other pulse, chickpea, for antihypertensive property in this in vitro study [50].

The same pea protein isolate from Nutri-Pea Limited was used again in Girgih et al.'s study as well, however, it was treated with thermoase GL30 for their protease [51]. Girgih et al. began with in vitro testing of ACE inhibition. [51]. The result was $\mathrm{PPH}$ being six times more potent in $\mathrm{ACE}$ conversion inhibition than renin inhibition with values of 0.10 $\mathrm{mg} / \mathrm{mL}$ and $0.57 \mathrm{mg} / \mathrm{mL}$ respectively [51]. Heat-treated PPI showed no effect in vitro of ACE or renin inhibition in this particular experiment [51].

30 spontaneous hypertensive male rats (systolic blood pressure (SBP) above $160 \mathrm{mmHg}$ ) were used in the in vivo portion of Girgih's experiment [51]. Of these, 6 rats were placed in each treatment: thermoase GL30 PPH (PPH-5), heattreated PPI (HTPPI), untreated PPI (UHPPI), positive control pharmaceutical ACE inhibitor captopril and negative control of saline solution for the short term (24h) systolic blood experiment [51]. The UHPPI showed to be ineffective to lower SBP significantly, peaking at $-4 \mathrm{mmHg}$ decrease 4 hours after oral administration, while heating it showed a large decrease in SBP, with the HTPPI SBP lowest at $-25 \mathrm{mmHg}$ after 6 hours [51]. The PPH-5 showed a more rapid onset to decrease the SBP than even the captopril at $1 / 10^{\text {th }}$ of a dosage, peaking at a $36 \mathrm{mmHg}$ drop between 2-4 hours, and had a prolonged effect [51].

From the previous short-term trial, 28 rats were placed into 4 groups this time for the long-term feeding study, not using UHPPI as a group [51]. The study did not state why two rats were omitted, nor which groups they originated from [51]. The results showed a dose-dependent effect of reducing blood 
pressure between the high dose and low dose PPH-5, suggesting there are bioactive components within the peptides, absorbable from the gastrointestinal tract [51]. The pre-digested PPH-5 low and high dose, which were $0.5 \%$ and $1 \% \mathrm{w} / \mathrm{w}$ respectively, showed better SBP-reducing effect than the unhydrolyzed HTPPI, with peak lowering values ranging from $-17 \mathrm{mmHg}$ to $-27 \mathrm{mmHg}$ less than the control group [51]. This peak occurred in the third week and remained significantly lower until the study concluded after week 5 [51]. Girgih suggested this slight increase after week 3 may be attributed to the oxidative stress of aging mice, in which would support the idea of PPI minimal role oxidative scavenging ability found in the previous study from Aluko and Humiski [51].

Lastly, the study also tested the SBP-lowering effects in normotensive rats, to test if hypotension would occur [51]. The results showed no significant changes in SBP compared to the control in both high dose PPH-5 and HTPPI [51].

One more rat study was done via Li et al., this time using Nutri-Lea PPI [52]. In the short term study of 24 hours - using spontaneous hypertensive rats-PPI did not elicit a significant effect on blood pressure, however treating PPI with thermolysin to make a hydrolysate did show significant antihypertensive effects [52]. In the long term portion of the study, high and low dose of $0.5 \%$ and $1 \% \mathrm{PPH}$ w/w of diet respectively, only started significantly lower SBP after 6 weeks, however no data was shown prior to week 4 [52]. By week 8, about a -30 mmHg decrease in SBP was maintained in both dosages [52]. There was also an approximately $45 \%$ decrease in plasma AII concentrations for both dosages as well [52]. The plasma ACE activity did not change, however, potentially suggesting another molecular mechanism other than ACE inhibition, contradicting previous studies showing ACE inhibition in vitro [52]. To support this idea, both renin and ACE mRNA expression in the kidney was measured and only the renin mRNA was significantly decreased by approximately $50 \%$, similar to the decreased plasma AII value [52].

This study went to human trials with seven participants, 3 male and 4 female, in a double blind placebo-controlled crossover intervention trial [52]. These participants were between the ages of 30-55 years, non-smokers, taking no antihypertensive drugs and had SBP between 125-170 $\mathrm{mmHg}$ [52]. The trials showed an average of 5 and $6 \mathrm{mmHg}$ reductions in weeks 2 and 3 of the trials for $3 \mathrm{~g} /$ day of the thermolysin-derived PPH group, however, no significant difference between the control and the $1.5 \mathrm{~g} /$ day of thermolysin-derived PPH group [52]. The peak reduction of the trials was $10 \mathrm{mmHg}$, producing a slightly higher effect than the average of $9.1 \mathrm{mmHg}$ obtained from a meta-analysis of the five different families of antihypertensive drugs at standard dose $[52,53]$. Most notably, this had that effect without any reported adverse side effects, and no toxic dose has been reported, in addition to the suggested no hypotensive risk previously discussed [52]. This human intervention did contain significant findings, however, due to the small sample size of $n=7$, more interventions will be needed for more reliability.

The research from these important cardiovascular based studies can go into two directions moving forward. First, identifying what the bioactive component is, and finding the molecular mechanism of how the bioactive elicits its effect on the RAAS. Another important direction in this is the applicability to human nutrition. Specifically, if this bioactive component of pea protein isolate can be activated by naturally expressed human proteases, when not previously treated. If so, the large amounts of commercial products containing PPI as well as supplementation could produce significant effects on human blood pressure.

\section{Summary}

Evaluating PPI as a protein source demonstrated its high digestibility. This, combined with high BCAA content, proved it to be a favourable protein over other plant-based alternatives. It was also important to note that it was low in one essential amino acid, methionine. PPI was also explored at a genotoxic level and passed all three tests against genetic damage, suggesting that PPI is safe to consume. Two separate studies showed that PPI's anabolic effect is capable of being an equivalent alternative to whey, in both high intensity and resistance exercise. PPI's glycaemic-lowering effect was only shown in one study, however its effect was still evident. PPI's ability to induce satiety was shown in both animal and human studies, inducing very similar response curves of anorexigenic hormones PYY and GLP-1 to that of whey protein. The glucose response curve was also measured during this, showing a more gradual increase over time in blood glucose, as opposed to a rapid spike. There was one study that used PPI's nanoemulsion as a fortification mechanism to increase the vitamin $\mathrm{D}$ levels in deficient mice

The effect that has received the most attention in literature is its cardiovascular effects. First looking at its hypolipidemic effects, two rat studies aimed to find the mechanism behind the decrease in VLDL, liver cholesterol, plasma cholesterol and plasma triglycerides observed. The increased bile acid excretion could be attributed due to the upregulated CYP7A1 concentrations, or the effect could be attributed to it due to a reduced proteolytic activation of SREBP-1c thus reducing its activated transcription factor. Blood pressure was evaluated in vitro, in animal models and in human models, all eliciting a hypotensive effect. While the initial in vitro studies suggested the mechanism might be ACE inhibition, one animal study found that the ACE activity itself did not change, instead they found a large decrease in plasma AII and renin mRNA. Oxidative stress was studied as well, however its scavenging ability of free radicals seemed to exist, although the effects were low. The effects of PPI are clearly widespread and can have large beneficial implications in human nutrition, however, more research needs to be done before PPI becomes a player in the additives and supplements market. 


\section{Acknowledgements}

This paper was written under the supervision of Dr. Jennifer Monk in the course HK 4320. There were no funding sources or conflicts of interest for this paper.

\section{References:}

1. Fredrikson, M., et al., Production Process for HighQuality Pea Protein Isolate with Low Content of Oligosaccharides and Phytate. 2001, Journal of Agriculture and Food Chemistry. p. 1208-1212.

2. Lam, A., et al., Pea Protein Isolates: Structure, extraction and functionality. 2018: Food Reviews International.

3. Rungruangmaitree, R. and W. Jiraungkoorskul, Pea, Pisum Sativum, and Its Anticancer Activity. 2017: Pharmacognosy reviews. p. 39-42.

4. Acheson, J., Pea Protein Isolate in Food and Beverage Products. 2016, Agriculture and AgriFood Canada.

5. Gorissen, S., et al., Protein content and amino acid composition of commercially available plant-based protein isolates. 2018: Amino Acids. p. 1685-1695.

6. Consultation, J.W.F.U.E., Protein and amino acid requirements in human nutrition. 2007, World Health Organization: World Health Organization technical report series. p. 1-265.

7. Seite, S., et al., Dietary methionine deficiency affects oxidative status, mitochondrial integrity and mitophagy in the liver of rainbow trout (Oncorhynchus mykiss). 2018: Scientific Reports.

8. Blomstrand, E., et al., Branched-chain amino acids activate key enzymes in protein synthesis after physical exercise. 2006: The Journal of Nutrition.

9. Yang, H., et al., Evaluation of nutritional quality of a novel pea protein. 2012: AgroFOOD. p. 8-10.

10. Adebiyi, A. and R. Aluko, Functional properties of protein fractions obtained from commercial yellow field pea (Pisum sativum L.) seed protein isolate. 2011: Food Chemistry. p. 902-908.

11. Pellevoisin, C., C. Bouez, and J. Cotovio, Cosmetic industry requirements regarding skin models for cosmetic testing. 2017: Skin Tissue Models. p. 3-37.

12. Aouatif, C., et al., Genotoxicological Evaluation of NUTRALYS Pea Protein Isolate. 2013: International Scholarly Research Network of Toxicology.

13. Almajwal, A., et al., Stabilization of Vitamin D in Pea Protein Isolate Nanoemulsions Increases Its Bioefficacy in Rats. 2019: Nutrients.

14. Fuhrman, J. and D. Ferreri, Fueling the vegetarian (vegan) athlete. 2010: Current sports medicine reports. p. 233-241.

15. Candow, D., et al., Effect of whey and soy protein supplementation combined with resistance training in young adults. 2006: International Journal of Nutritional Exercise Metabolism. p. 233-244.

16. Denysschen, C., et al., Resistance training with soy vs whey protein supplements in hyperlipidemic males. 2009: Journal of the International Society of Sports Nutrition.

17. Hartman, J., et al., Consumption of fat-free fluid milk after resistance exercise promotes greater lean mass accretion than does consumption of soy or carbohydrate in young, novice, male weighlifters. 2007: The American journal of clinical nutrition.

18. Phillips, S., J. Tang, and D. Moore, The role of milkand soy-based protein in support of muscle protein synthesis and muscle protein accretion in young and elderly persons. 2009: Journal of the American College of Nutrition.

19. Volek, J., et al., Whey protein supplementation during resistance training augments lean body mass. 2013: Journal of the American College of Nutrition.

20. Patisaul, H. and W. Jefferson, The pros and cons of phytoestrogens. 2010: Frontiers in neuroendocrinology.

21. Jargin, S., Soy and phytoestrogens: possible side effects. 2014: German Medical Science.

22. Kurzer, M., Hormonal effects of soy in premenopausal women and men. 2002: The Journal of Nutrition. p. 570-573.

23. Multari, S., et al., Nutritional and Phytochemical Content of High-Protein Crops. 2016: Journal of Agriculture Food Chemistry.

24. Babault, N., et al., Pea proteins oral supplementation promotes muscle thickness gains during resistance training: a double-blind, randomized, Placebocontrolled clinical trial vs. Whey protein. 2015: Journal of the International Society of Sports Nutrition.

25. Banaszek, A., et al., The Effects of Whey vs. Pea Protein on Physical Adaptations Following 8-weeks of High-Intensity Functional Training (HIFT): A Pilot Study. 2019: Multidisciplinary Digital Publishing Institute.

26. Forde, C., E. Almiron-Roig, and J. Brunstrom, Expected Satiety: Application to Weight Management and Understanding Energy Selection in Humans. 2016: Current obesity reports. p. 131-140.

27. Smith, C., et al., The effect of yellow pea protein and fibre on short-term food intake, subjective appetite and glycaemic response in healthy young men. 2012: British Journal of Nutrition. p. 74-80.

28. Overduin, J., et al., NUTRALYS pea protein: characterization of in vitro gastric digestion and in vivo gastrointestinal peptide responses relevant to satiety. 2015: Food and Nutrition Research.

29. Sacks, F., et al., Soy Protein, Isoflavones, and Cardiovascular Health. 2006: American Heart Association Journals. p. 1034-1044. 
30. Zhang, J., et al., Effect of whey protein blood lipid profiles: a meta-analysis of randomized controlled trials. 2016: European Journal of Clinical Nutrition. p. 879-885.

31. Spielmann, J., G.I. Stangl, and K. Eder, Dietary pea protein stimulates bile acid excretion and lowers hepatic cholesterol concentration in rats. 2008: Journal of Animal Physiology and Animal Nutrition.

32. Rigamonti, E., et al., Hypolipidemic effect of dietary pea proteins: Impact on genes regulating hepatic lipid metabolism. 2009: Molecular Nutrition and Food Research. p. 24-30.

33. VanderLaan, P., et al., VLDL best predicts aortic root atherosclerosis in LDL receptor deficient mice. 2009, American Society for Biochemistry and Molecular Biology: Journal of Lipid Research. p. 376-385.

34. Linton, M., et al., The Role of Lipids and Lipoproteins in Atherosclerosis. 2000: South Dartmouth

35. Boren, J., et al., Low-density lipoproteins cause atherosclerotic cardiovascular disease: pathophysiological, genetic, and therapeutic insights: a consensus statement from the European Atherosclerosis Society Consensus Panel. 2020, European Heart Journal. p. 2313-2330.

36. Xie, X., et al., Association of very Low-density Lipoprotein Cholesterol with All-cause and Cardiovascular Mortality in Peritoneal Dialysis. 2017: Kidney Blood Press Res.

37. Vlahcevic, Z.R., W.M. Pandak, and R.T. Stravitz, Regulation of bile acid biosynthesis. 1999: Gastroenterology Clinics of North America. p. 1-25.

38. Beynen, A.C., Mode of hypocholesterolemic action of protocol in animals and man. 1987: Artery. p. 113126.

39. Grosskopf, I., et al., The association of bile acid excretion and atherosclerotic coronary artery disease. 2011: Therapeutic Advances in Gastroenterology. p. 95-101.

40. Tada, H., A. Nohara, and M. Kawashiri, Serum Triglycerides and Atherosclerotic Cardiovascular Disease: Insights from Clinical and Genetic Studies. 2018: Nutrients.

41. Fountain, J. and S. Lappin, Physiology, Renin Angiotensin System. 2019, StatPearls Publishing.

42. Rani, V. and U.C.S. Yadac, Free Radicals in Human Health and Disease. 2015, Springer India. p. 270274.

43. Kou, T., et al., Effect of soybean protein on blood pressure in postmenopausal women: a meta-analysis of randomized controlled trials. 2017: Food and Function. p. 2663-2671.

44. Yang, J., et al., Effect of whey protein on blood pressure in pre- and mildly hypertensive adults: A randomized controlled study. 2019: Food Science and Nutrition. p. 1857-1864.
45. Fekete, A., et al., Whey protein lowers blood pressure and improves endothelial function and lipid biomarkers in adults with prehypertension and mild hypertension: results from the chronic Whey2Go randomized controlled trial. 2016: The American Journal of Clinical Nutrition. p. 1534-1544.

46. Humiski, L. and R. Aluko, Physicochemical and Bitterness Properties of Enzymatic Pea Protein Hydrolysates. 2007: Journal of Food Science.

47. Tsai, J., T. Lin, and B. Pan, The inhibitory effects of freshwater clam ( Corbicula fluminea , Muller) muscle protein hydrolysates on angiotensin I converting enzyme. 2006: Process Biochemistry. p. 2279.

48. Li, B., et al., Isolation and identification of antioxidative peptides from porcine collagen hydrolysate by consecutive chromatography and electrospray ionization-mass spectrometry 2007: Food Chemistry.

49. Zhu, K., H. Zhou, and H. Qian, Antioxidant and free radical-scavenging activities of wheat germ protein hydrolysates (WGPH) prepared with alcalase. 2006: Process Biochemistry. p. 1296-1302.

50. Barbana, C. and J. Boye, Angiotensin I-converting enzyme inhibitory activity of chickpea and pea protein hydrosylates. 2010, Food Research International. p. 1642-1649.

51. Girgih, A., et al., Antihypertensive Properties of a Pea Protein Hydrolysate during Short- and LongTerm Oral Administration to Spontaneously Hypertensive Rats. 2016: Journal of Food Science. p. 1281-1285.

52. Li, H., et al., Blood Pressure Lowering Effect of a Pea Protein Hydrosylate in Hypertensive Rats and Humans. 2011, Journal of Agriculture and Food Chemistry. p. 9854-9860.

53. Law, M., N. Wald, and R. Jordan, Value of low dose combination treatment with blood pressure lowering drugs: analysis of 354 randomized trials. 2003, British Medical Journal. p. 1427. 


\section{Tables}

Table 1. Data Extraction Table of Pea Protein Isolate Health Benefits

\begin{tabular}{|c|c|c|c|c|c|c|}
\hline Study and Year & Study Type & Reference & Participants & Control & Dose & Effect \\
\hline $\begin{array}{l}\text { Smith et al., } \\
2012\end{array}$ & $\begin{array}{l}\text { Single-blind, } \\
\text { randomized, } \\
\text { placebo controlled } \\
\text { clinical trial }\end{array}$ & [27] & 19 humans & Tomato soup & $\begin{array}{l}10 \mathrm{~g} \text { and } 20 \mathrm{~g} \\
\text { groups }\end{array}$ & $\begin{array}{l}\text { Decreased } \\
\text { blood glucose } \\
\text { and increased } \\
\text { subjective } \\
\text { satiety }\end{array}$ \\
\hline $\begin{array}{l}\text { Overduin et al., } \\
2015\end{array}$ & $\begin{array}{l}\text { In vitro, } \\
\text { experimental } \\
\text { animal cohort trial }\end{array}$ & [28] & 12 rats & Carbohydrate & $\begin{array}{l}3.5 \mathrm{~g} \text { of PPI per } \\
10 \mathrm{~g} \text { meal }\end{array}$ & $\begin{array}{l}\text { Decreased } \\
\text { blood glucose } \\
\text { and increased } \\
\text { CCK levels }\end{array}$ \\
\hline $\begin{array}{l}\text { Spielmann et } \\
\text { al., } 2007\end{array}$ & $\begin{array}{l}\text { In vitro, } \\
\text { experimental } \\
\text { animal cohort } \\
\text { trials }\end{array}$ & [31] & 24 rats & Casein & $200 \mathrm{~g} / \mathrm{kg} \mathrm{BW}$ & $\begin{array}{l}\text { Increased fecal } \\
\text { bile acid } \\
\text { excretion, }\end{array}$ \\
\hline $\begin{array}{l}\text { Rigamonti et } \\
\text { al., } 2009\end{array}$ & $\begin{array}{l}\text { In vitro, } \\
\text { experimental } \\
\text { animal cohort } \\
\text { trials }\end{array}$ & [32] & 24 rats & Casein & $\begin{array}{l}20 \% \text { of diet } a d \\
\text { libitum }\end{array}$ & $\begin{array}{l}\text { Lower total } \\
\text { plasma } \\
\text { cholesterol and } \\
\text { triglyceride } \\
\text { levels }\end{array}$ \\
\hline $\begin{array}{l}\text { Babault et al., } \\
2015\end{array}$ & $\begin{array}{l}\text { Double-blind } \\
\text { randomized, } \\
\text { placebo controlled } \\
\text { clinical trial }\end{array}$ & [24] & 161 humans & $\begin{array}{l}\text { Whey protein and } \\
\text { placebo }\end{array}$ & $25 \mathrm{~g}$ twice daily & $\begin{array}{l}\text { Increase in } \\
\text { muscle } \\
\text { thickness }\end{array}$ \\
\hline $\begin{array}{l}\text { Banaszek et al., } \\
2019\end{array}$ & $\begin{array}{l}\text { Double-blind } \\
\text { randomized } \\
\text { clinical trial }\end{array}$ & [25] & 15 humans & Whey protein & $24 \mathrm{~g}$ twice daily & $\begin{array}{l}\text { Increase in } \\
\text { muscle strength }\end{array}$ \\
\hline $\begin{array}{l}\text { Humiski and } \\
\text { Aluko, } 2007\end{array}$ & In vitro & [46] & $\mathrm{n} / \mathrm{a}$ & Buffer solution & $\begin{array}{l}1 \mathrm{mg} / \mathrm{mL} \quad \mathrm{PPH} \\
\text { in } \mathrm{V}=175 \mu \mathrm{L}\end{array}$ & $\begin{array}{l}\text { ACE inhibition } \\
\text { and slight free } \\
\text { radical } \\
\text { scavenging } \\
\text { effect }\end{array}$ \\
\hline $\begin{array}{l}\text { Barbana and } \\
\text { Boye, } 2010\end{array}$ & In vitro & [50] & $\mathrm{n} / \mathrm{a}$ & $\mathrm{n} / \mathrm{a}$ & $\begin{array}{l}0-0.7 \mathrm{mg} / \mathrm{mL} \text { of } \\
\text { PPH }\end{array}$ & $\begin{array}{l}\text { Dose } \\
\text { dependent } \\
\text { ACE inhibition }\end{array}$ \\
\hline $\begin{array}{l}\text { Girgih et al., } \\
2016\end{array}$ & $\begin{array}{l}\text { In vitro, } \\
\text { experimental } \\
\text { animal cohort trial }\end{array}$ & [51] & 30 rats & Saline solution & $\begin{array}{l}100 \mathrm{mg} / \mathrm{kg} \mathrm{BW} \\
\text { for short term } \\
\text { study, } 0,0.5 \\
\text { and } 1 \% \mathrm{w} / \mathrm{w} \text { of } \\
\text { feed for long- } \\
\text { term }\end{array}$ & $\begin{array}{l}\text { ACE inhibition } \\
\text { and slight renin } \\
\text { inhibition, } \\
\text { lowers SBP in } \\
\text { spontaneous } \\
\text { hypertensive } \\
\text { rats but not } \\
\text { normotensive } \\
\text { rats }\end{array}$ \\
\hline
\end{tabular}


Health Benefits of Pea Protein Isolate: A Comparative Review (Stilling)

\begin{tabular}{|c|c|c|c|c|c|c|}
\hline \multirow[t]{2}{*}{$\begin{array}{l}\text { Li H et al., } \\
2011\end{array}$} & $\begin{array}{l}\text { Experimental } \\
\text { animal cohort } \\
\text { study }\end{array}$ & \multirow[t]{2}{*}{ [52] } & $\begin{array}{l}30 \text { rats for short- } \\
\text { term effect and } \\
39 \text { rats for long- } \\
\text { term effect }\end{array}$ & Casein & $\begin{array}{l}0, \quad 100 \text { and } \\
200 \mathrm{mg} / \mathrm{kg} \text { BW } \\
\text { of PPH and } \\
200 \mathrm{mg} / \mathrm{kg} \text { BW } \\
\text { of PPI for } \\
\text { short-term, } \\
0,0.5 \text { and } 1 \% \\
\text { w/w of feed for } \\
\text { long-term }\end{array}$ & $\begin{array}{l}\text { Lower SBP, } \\
\text { decreased AII } \\
\text { levels but no } \\
\text { difference in } \\
\text { ACE activity } \\
\text { which may be } \\
\text { due to } \\
\text { decreased renal } \\
\text { mRNA levels }\end{array}$ \\
\hline & $\begin{array}{l}\text { Randomized } \\
\text { double-blinded } \\
\text { placebo-controlled } \\
\text { crossover clinical } \\
\text { trial }\end{array}$ & & 7 humans & Placebo & $\begin{array}{l}1.5 \text { and } 3 \mathrm{mg} \text { of } \\
\mathrm{PPH} / \text { day }\end{array}$ & Lower SBP \\
\hline
\end{tabular}

